Katarzyna Burska

Uniwersytet Łódzki

\title{
JĘZYKOWE SPOSOBY OPISYWANIA POLAKÓW \\ I ICH GRUPOWYCH RYWALI PODCZAS EURO 2012 \\ W WYBRANYCH DZIENNIKACH
}

SŁOWA KLUCZOWE: Euro 2012, relacje sportowe, piłka nożna, metaforyka

Mistrzostwa Europy w piłce nożnej organizowane w 2012 r. w Polsce i na Ukrainie były ważnym wydarzeniem nie tylko sportowym, ale także kulturalnym. Informacje dotyczące turnieju pojawiały w czerwcu we wszelkich mediach praktycznie przez całą dobę. Do Polski przybyły niezliczone rzesze kibiców z całego świata pragnących przeżyć piłkarskie emocje, ale także poznać historię i kulturę naszego kraju, obowiązujące tradycje i zwyczaje. 3 grudnia 2011 r. w Kijowie odbyło się losowanie grup finałowych Euro 2012, wówczas okazało się, że Polska zmierzy się z Grecją, Rosją oraz Czechami. Dobór przeciwnikówjużodsamegopoczątkustałsiętematemlicznychkomentarzy,któreprzybrały na sile wraz z przybyciem poszczególnych drużyn narodowych do naszej ojczyzny.

Celem artykułu jest ukazanie obrazu reprezentantów Polski oraz ich grupowych rywali podczas czempionatu Starego Kontynentu. Za pomocą jakich środków językowych przedstawiano piłkarzy należących do tych narodowości? Na jakie elementy zwrócono szczególną uwagę? Czy wpływ na opis miały zaszłości historyczne? W jaki sposób dokonywano wartościowania? Analizie poddano artykuły pojawiające się w „Przeglądzie Sportowym”, „Gazecie Wyborczej”, „Dzienniku Łódzkim Polska The Times” i „Fakcie” $\mathrm{w}$ dniu meczu oraz dzień po spotkaniu (lub dwa dni — w przypadku, gdy pojedynek rozgrywany był w sobotę).

Marcin Kalita, redaktor naczelny „Przeglądu Sportowego”, tak pisał w swoim artykule opublikowanym w dniu inauguracji mistrzostw Europy:

Dziś jest pierwszy dzień nowej historii. Historii naszego futbolu, ale i kraju. Co najbardziej niezwykłe w tej sytuacji — że dzieje Polski zostaną zapisane przez dzieje futbolu. To nas różni od Francuzów, Anglików, Niemców czy Włochów. Dla nich podobnie wielkie imprezy sportowe zbliżają się, są, przemijają. Dla nas EURO to wielkie, dziejowe „bum”, cezura do zapamiętania na zawsze.

(PS, 08.06.2012, s. 2)

${ }^{1} \mathrm{~W}$ artykule posłużono się następującym skrótami na oznaczenie źródeł: PS - „Przegląd Sportowy”, F - „Fakt”, GW - „Gazeta Wyborcza”, GWS - dodatek sportowy do „Gazety Wyborczej” „Gazeta Sport.pl Euro 2012”, DŁ - „Dziennik Łódzki Polska The Times”, DŁE - dodatek sportowy do „Dziennika Łódzkiego Polska The Times” „Dziennik Łódzki na Euro 2012”. 
W słowach tych, przepełnionych wzniosłością, podkreślał zatem, że rozgrywany na polskich i ukraińskich boiskach turniej jest wydarzeniem dziejowym i - w przeciwieństwie do innych europejskich nacji — będziemy o nim pamiętać przez lata, gdyż odegra wielką rolę w historii naszego kraju.

O randze mistrzostw i niepowtarzalnej szansie, jaka stoi przed zawodnikami nie tylko Polakami, ale także naszymi grupowymi przeciwnikami - w przypadku zwycięstwa, świadczyły używane często patetyczne sformułowania. Przywoływano wysokie uczucie, które może wywołać w odbiorcach sportowego widowiska postawa piłkarzy, powoływano się na takie wartości, jak: honor, duma, heroizm, jedność, wiara chrześcijańska, waleczność, zapewniano, że sukces przyniesie powody do radości całemu narodowi i pozwoli choć na chwilę zapomnieć o panującym kryzysie gospodarczym, porażka zaś sprawi, że reprezentanci dołączą niejako do grona męczenników:

Jeśli drużyna prowadzona przez Franciszka Smudę nas mile zaskoczy, jeśli będzie walczyć, szarpać, strzelać, porywać nasze serca i umysły, będziemy zadowoleni. Będziemy z lubością celebrować momenty sportowego uniesienia — dziś, jutro i za dziesięć lat.

(PS, 08.06.2012, s. 2)

Na drugą połowę Grecy wyszli wściekli. Oni też byli zdeterminowani. Nad wyraz często mówili o nieszczęściach, jakie spadły na ich kraj, zwierzali się, że w roli głównych oskarżonych w czasach kryzysu czują się kozłami ofiarnymi, opowiadali, jak bardzo zależy im, by dać przygnębionym rodakom powody do uśmiechu, choćby przez łzy.

(GW, 09.06.2012, s. 2)

Na pewno dali powody do dumy. Uratowali punkt, stoczyli heroiczną bitwę, podnieśli się po nokautujących ciosach, choć wyraźnie walczyli również z własnymi słabościami.

(GW, 09.06.2012, s. 2)

Na naszych oczach hartowała się polska drużyna, pełna zaciętości i waleczności, o której wreszcie można było powiedzieć, że jeden za drugiego skoczy w ogień.

(PS, 13.06.2012, s. 2)

Zwariowany mecz, nieziemskie tempo i zaskakujące zwroty akcji. A w środku tego wszystkiego polscy herosi wymieniający ciosy z Rosjanami, raz szaleńczo atakując, innym razem broniąc się zaciekle.

(PS, 13.06.2012, s. 2)

Rosjanie byli faworytami, Rosjanie zdobyli pierwszego gola, ale nam Bóg zesłał Kubę Błaszczykowskiego.

(F, 13.06.2012, s. I)

Od tej pory będą żyć z piętnem straconych nadziei — narodowego uniesienia, które zmienili w rozpacz. Dopisali kolejny rozdział, własny, do martyrologii polskiego futbolu.

(PS, 18.06.2012, s. 2)

Nasi piłkarze doprowadzili jednak temperaturę oczekiwań do poziomu wrzenia, a dumę narodową wynieśli na szczyty. Wierzyła w nich cała Polska.

(DŁE, 18.06.2012, s. 2) 
Na przeciwległym krańcu znajdują się z kolei wyrażenia zawierające słownictwo potoczne - używane zarówno do opisania negatywnej postawy reprezentantów:

Ale jednak pękliśmy — fizycznie.

(PS, 09.06.2012, s. 6)

(...) bądźmy szczerzy — dwa punkty straciliśmy wczoraj w sposób wyjątkowo frajerski.

(PS, 09.06.2012, s. 6)

Przerżnęliśmy te mistrzostwa pokazowo, mit o naszej genetycznej niezdolności do sensownego kopania gały pozostaje wiecznie żywy.

(GWS, 18.06.2012, s. 4)

jak i wyrażenia pochwały — zmobilizowania do lepszego występu:

Trzeba wziąć sprawy w swoje ręce, zapieprzać, zagrać ofensywnie, siąść na nich, przydusić, zdominować i wygrać.

(F, 16-17.06.2012, s. III)

Ale tak naprawdę nie można przyczepić się do żadnego z naszych zawodników. Zagrali świetnie jako zespół. Zapieprzali przez cały mecz i należą im się brawa.

(F, 13.06.2012, s. VIII)

Częstym jest, iż spotkanie drużyn ma wymiar nie tylko sportowy, ale jest także wydarzeniem politycznym. Zaszłości historyczne odegrały dużą rolę podczas pojedynku Polska - Rosja. Z doniesień medialnych można się było dowiedzieć, że konfrontacja na Stadionie Narodowym to coś więcej niż mecz. W zapowiedziach porównywano polskiego selekcjonera Franciszka Smudę do marszałka Józefa Piłsudskiego, pojawiały się nawiązania do bitwy warszawskiej zczasów wojny polsko-bolszewickiej:

Czy tym razem do pokonania Rosjan potrzebujemy cudu nad Wisłą? Nie.

(PS, 12.06.2012, s. 3)

Polacy odżegnują się od historycznych nawiązań, choć media nie pozwalają im od nich uciec, porównując Smudę do Józefa Piłsudskiego, który w 1920 roku pokonał bolszewików w Bitwie Warszawskiej.

(PS, 12.06.2012, s. 4)

Podglebie stosunków Polska - Rosja ma wymiar historyczny. Siłą rzeczy mecz staje się polityczną sprawą.

(GW, 12.06.2012, s. 4)

W spotkaniu Polski z Rosją doszukiwano się kontekstów historycznych. Wiele mówiło się także o polityce.

(DŁE, 12.06.2012, s. 2)

W artykułach nie brakowało nacechowanych pejoratywnie określeń odnoszących się do Rosjan - Ruscy, Moskale:

Bardzo bym chciał, by to był zwykły mecz sportowy, ale niech mi pan wskaże kogoś, kto będzie to tak traktował? (...) 99 procent naszych współobywateli będzie chciało, by dokopać Ruskim. To oczywiste.

(DŁ, 12.06.2012, s. 2) 
Najlepsza wiadomość wcale nie jest taka, że nie daliśmy się Moskalowi, co w naszym kraju ma wymiar daleko szerszy niż tylko piłkarski.

$$
\text { (PS, 13.06.2012, s. 6) }
$$

Dla innych, którzy starają się z faktów wydłubać też inne emocje, najważniejsze jest, że bijemy się z Ruskimi.

$$
\text { (DŁ, 12.06.2012, s. 3) }
$$

Podkreślano, że przyjdzie się zmierzyć z rywalem szczególnym, a ewentualny sukces będzie powodem do dużej radości:

Dach będzie otwarty, stres pierwszego tak istotnego meczu już minął, a i rywal, choć zdecydowanie mocniejszy od Greków — zawsze w Polaku wywołuje inną mobilizację i chęć wygrania.

(PS, 12.06.2012, s. 3)

Mecz z Rosją dla Polaków zawsze jest wyjątkowy. Nic nie smakuje tak słodko, jak wygrana $\mathrm{z}$ tym wielkim rywalem.

(PS, 12.06.2012, s. 9)

Rywalizacja polskich i radzieckich, a później rosyjskich sportowców obrosła legendami. (...) $\mathrm{Na}$ ogół była to walka małego z dużym. Choć polskie serca są wielkie i waleczne, to $\mathrm{w}$ sporcie bywaliśmy kopciuszkiem $\mathrm{w}$ porównaniu $\mathrm{z}$ radzieckim gigantem.

$$
\text { (DŁ, 12.06.2012, s. 3) }
$$

Dziennikarze, charakteryzując Rosjan, zwracali uwagę na ich słowiańskie korzenie:

To słowiańska natura z ogromną dumą i przekonaniem o własnej wyższości. Ciężko im się adaptować do nowych warunków, wszystko ma być tak, jak oni chcą. (...) Nie ma mowy, by nas zlekceważyli. Są przekonani o swojej wyższości i będą chcieli jak najszybciej pokazać to na boisku. Rozluźnią się dopiero wtedy, gdy w meczu z nami zapewnią sobie awans.

(GWS, 12.06.2012, s. 2)

Przy okazji spotkania z Grecją odnotowano nawiązania mitologiczne — pisano o herosach czy potomkach atletów z Hellady:

Przyjemnym zaskoczeniem było to, że to Polacy forsowali tempo, sprawiali wrażenie lepiej przygotowanych motorycznie od Greków, byli szybsi i ustawali na nogach fizyczne pojedynki, mocnych zazwyczaj potomków atletów z Hellady.

$$
\text { (DŁE, 09.06.2012, s. 1) }
$$

(...) herosami nie jesteśmy (akurat Grecy też nie).

$$
\text { (PS, 08.06.2012, s. 5) }
$$

W walce $\mathrm{z}$ greckimi atletami nie będzie osamotniony.

(GWS, 08.06.2012, s. 3)

w jednym porównaniu — by podkreślić bezradność zawodników — wykorzystano nazwę miejsca kultu w Atenach:

Grecy w tym czasie stali jak posągi na Akropolu.

$$
\text { (PS, 09.06.2012, s. 6) }
$$

Z kolei w zapowiedzi meczu otwarcia, w celu precyzyjnego określenia piłkarzy z Europy Południowej, posłużono się bogatą, rozbudowaną metaforą, w której 
wyraźnie widoczne były skojarzenia z mitem o wojnie trojańskiej, przywoływanym niejednokrotnie $\mathrm{w}$ dziełach starożytnych pisarzy:

Wróg jest tym bardziej niebezpieczny, że nie ma twarzy — znów trzeba powtórzyć, że kiedy słyszymy, iż Grecy nie wychowali piłkarskich gwiazd, słyszymy prawdę niepełną. Wiarygodniej byłoby powiedzieć, że cała grecka strategia polega na tym, by zlać się $\mathrm{w}$ jedną nieprzeniknioną masę i zamaskować totalnie. (...) Nigdy nie wiesz, kto okaże się koniem trojańskim, z którego znienacka wylezie rębajło. Oczywiście wylezie akurat wtedy, gdy nasi przysną.

(GWS, 08.06.2012, s. 4)

Ciekawym rozwiązaniem było także sięgnięcie do zasobów kulturalnych kraju i przytoczenie greckiej sentencji:

Cierpliwość jest kluczem do szczęścia - głosi greckie przysłowie. I rzeczywiście, nasi rywale nie rzucają się na przeciwnika, ustawiają się na własnej połowie i czekają na okazję.

(PS, 08.06.2012, s. 5)

Na uwagę zasługuje też zabawa słowami wykorzystująca skojarzenia kulinarne. W felietonie podsumowującym mecz Polska - Grecja pojawiło się zdanie:

Nie było „sałatki po grecku”, nie spełniło się też moje marzenie o „Rybce po grecku”.

(PS, 09.06.2012, s. 8)

Na pierwszy rzut oka mogłoby się wydawać, że autor wymienia nazwy potraw, ale sałatka po grecku oznacza tu pogrom zawodników z Półwyspu Peloponeskiego, Rybka po grecku zaś - dobry występ naszego gracza ${ }^{2}$.

Posługiwanie się różnorodnymi przenośniami stało się popularnym zabiegiem $\mathrm{w}$ artykułach przed- i pomeczowych — kreatywne, zadziwiające bogactwem połączeń wyrazowych metafory pozwalały lepiej uświadomić czytelnikom, jakie uczucia towarzyszyły kibicom podczas konfrontacji z Grecją:

Polscy piłkarze wsadzili wczoraj kibiców do rollercoastera, który pędził z nieba do piekła i z powrotem.

(F, 09.06.2012, s. IV)

czego można oczekiwać od Rosjan:

To nie będzie, niestety, przemarsz przez Warszawę, lecz naloty dywanowe na polskie pole karne.

(GW, 12.06.2012, s. 1)

jakie emocje wywołała porażka z Czechami i odpadnięcie z turnieju:

Wielkie krople spadające na naszych reprezentantów ważyły tyle, ile oczekiwania 38 milionów Polaków. Piłkarze okazali się na to nieprzygotowani, padli pod ciężarem nadziei rodaków.

(PS, 18.06.2012, s. 2)

${ }^{2}$ By właściwie zinterpretować to połączenie leksykalne, niezbędna jest znajomość pseudonimów polskich piłkarzy — w przykładzie tym wykorzystano przydomek Rybka, który przylgnął do pomocnika Macieja Rybusa. 
jakimi cechami odznaczają się zawodnicy:

Marcin Wasilewski to taka tykająca bomba zegarowa, mam nadzieję, że jego temperament nie spowoduje eksplozji.

$$
\text { (F, 08.06.2012, s. II) }
$$

35-letni wychowanek Panathinaikosu (...) jest dla reprezentacji nieoceniony. Na boisku nie wyróżnia się wzrostem $(176 \mathrm{~cm})$, ale to serce i mózg drużyny.

(GWS, 08.06.2012, s. 6)

Rosjanie zagrali przeciwko Czechom imponująco w ofensywie, ale nie są piłkarskimi bogami. Arszawin, tak wychwalany po jednym meczu Dzagojew, Kierżakow, Pawluczenko, wspomniani stoperzy, Małafiejew — owszem - mają w sobie futbolową iskrę bożą, ale mają i za pazuchą schowanego piłkarskiego lenia.

(PS, 12.06.2012, s. 3)

\section{Równie chętnie jak po metafory dziennikarze sięgali po niestandardowe po-} równania. $\mathrm{Za}$ ich pomocą opisywano nieprzeciętne umiejętności zawodników:

Reprezentację Polski zasiliło też kilku graczy tak znakomitych, jakby zrzucili ich z kosmosu.

(GW, 08.06.2012, s. 1)

postawę na boisku:

Grecy są mocniejsi, niż przeciętny kibic sądzi. Dryblasy, perfekcyjnie zorganizowani, grający beznamiętnie, jakby bez układu nerwowego.

(GW, 08.06.2012, s. 1)

Niestety w drugiej połowie wyglądało to tak, jakby naszym odcięto prąd.

(PS, 09.06.2012, s. 9)

Biało-czerwona machina funkcjonowała jak szwajcarski zegarek.

(GWS, 13.06.2012, s. 2)

Polacy potrzebowali zwycięstwa. I zaczęli, jak przystało na drużynę grającą z nożem na gardle. Napadli na gości, jak pewny siebie gospodarz, który chce tylko wziąć, co mu należne.

(PS, 18.06.2012, s. 2)

sposób gry:

Razem z kolegami poruszają się po polu karnym jak po wytyczonych ścieżkach: nie zabiegają sobie drogi, każdy wie, jak minąć rywala.

(GWS, 08.06.2012, s. 5)

Trwało przeciąganie liny, piłkarze Dicka Advokaata kilka razy wymieniali ze sobą piłkę w taki sposób, jakby chcieli pokazać światu rosyjską wersję tiki-taki, delektując się niezliczoną ilością podań.

(PS, 13.06.2012, s. 2)

determinację trenera i graczy:

Nie tylko selekcjoner czuł się w ostatnich dniach jak zwierz w klatce, który — wypuszczony

— rozszarpałby wszystko, co staje mu na drodze. Jego zawodnicy też.

(PS, 08.06.2012, s. 4) 
siłę uderzenia:

Nie dał rady Lewandowski, wyręczył go Błaszczykowski. (...) huknął w piłkę - lewą stopą, tą słabszą! - jakby chciał, żeby się rozpadła (...).

(GW, 13.06.2012, s. 1)

Nie brakuje także epitetów - prostych i złożonych — których zadaniem jest podkreślenie cech zawodników:

Piłkarzy, którzy zostali pobici w Hiszpanii, już nie ma. Zastąpili ich faceci pewni siebie, świadomi własnych umiejętności.

(PS, 08.06.2012, s. 5)

Najmłodszy zespół od lat, głodny zwycięstw jak żadna poprzednia reprezentacja, ma niepowtarzalną szansę, aby nawiązać do udanych występów reprezentacji Polski z lat 80 .

umiejętności:

(F, 08.06.2012, s. II)

Grecy? Zdyscyplinowani, pewni siebie i zabójczo skuteczni.

(DŁE, 08.06.2012, s. 2)

Na prawym skrzydle Rosjan rządzi bowiem groźny Ałan Dzagojew (...). Wspierać go będzie wszędobylski i dynamiczny Andriej Arszawin (31 1.).

sposobu zachowania:

(F, 12.06.2012, s. I)

Zobaczyliśmy piłkarzy zdeterminowanych, nabuzowanych, gotowych zaprzedać dusze diabłu, byleby tylko wygrać.

(PS, 09.06.2012, s. 2)

Grecy długo nie mogli nic zrobić, napotkali drużynę pewną każdego swojego ruchu, sterowaną przez wszędobylskiego Rafała Murawskiego i Eugena Polanskiego (...).

(PS, 09.06.2012, s. 2)

systemu gry:

Rosjanie wyprowadzają je w oszałamiającym tempie, a mimo to podają sobie piłkę $\mathrm{z}$ laserową precyzją.

(GW, 12.06.2012, s. 1)

Odnotowano także epitet metaforyczny, który miał uzmysłowić, jak szybkie akcje przeprowadzali nasi przeciwnicy:

Ale tak samo reagowali Rosjanie. Tempo ich akcji na naszej połowie napędzane było chyba paliwem rakietowym, dawno już polscy obrońcy nie przeżyli takiej nawałnicy, jaką zorganizowali im goście.

(PS, 13.06.2012, s. 2)

W zdecydowanej większości epitety służą wartościowaniu, wyrażeniu oceny, waloryzacji. Widowisku sportowemu towarzyszą niejednokrotnie olbrzymie emocje, więc już sam dobór słownictwa jest nierzadko ich wykładnikiem. Jak twierdzi M. Koper: Przymiotniki te zazwyczaj dookreślaja stan emocjonalny nadawcy. Najczęściej występuja w funkcji epitetów emotywnych, które charakteryzuja się najwyższym stopniem intensywności semantycznej. Sa to połączenia rzeczowników z emo- 
cjonalnymi przydawkami, które nadaja wyrażeniom wyraźne zabarwienie emocjonalne [2009, s. 70]. Wyrazy te mają charakter prymarnie wartościujący, ich celem jest intensyfikacja przeżyć odbiorców [Szkudlarek-Śmiechowicz, 2006]:

Polacy zaczęli imponująco, agresywnie na połowie rywala, z kapitalną asekuracją partnerów, $\mathrm{a}$ - co najważniejsze — $\mathrm{z}$ pomysłem na grę ofensywną.

$$
\text { (F, 09.06.2012, s. IV) }
$$

Polacy świetnie zagrali w drugiej połowie i po fantastycznym strzale Kuby Błaszczykowskiego zremisowali z faworytami grupy A.

(PS, 13.06.2012, s. 2-3)

Odpadamy z EURO jako najgorszy gospodarz w historii turnieju.

(PS, 18.06.2012, s. 2)

Boję się meczu z Grecją. To bardzo solidna drużyna, ma świetną defensywę, jest wyrachowana.

$$
\text { (F, 08.06.2012, s. II) }
$$

Zaczęliśmy naprawdę dobrze, stwarzaliśmy dobre okazje do strzelenia gola. (...) Przeprowadziliśmy kilka ładnych akcji prawą stroną.

(PS, 09.06.2012, s. 8)

Jestem bardzo mocny rozczarowany grą Polaków. Pokazali mizerny futbol.

$$
\text { (PS, 09.06.2012, s. 9) }
$$

Kuba Błaszczykowski przyłożył Rosjanom najpiękniejszym jak dotąd golem na mistrzostwach.

$$
\text { (GW, 13.06.2012, s. 1) }
$$

Okazało się, że Czesi zagrali dobre spotkanie i potrafili nas zdominować.

(F, 18.06.2012, s. III)

Drużyny, z którymi przyszło nam się mierzyć w fazie grupowej Euro 2012, nazywano najczęściej rywalami lub przeciwnikami - wyrazy te zwykle były obudowane połączeniami leksykalnymi, które opisywały styl ich gry:

Jest to przeciwnik, który nie pozwoli sobie na otwartą grę i nie da Polakom możliwości kontr, czyli tego, co kochają najbardziej.

(GWS, 08.06.2012, s. 3)

Poza tym nasi przeciwnicy nie strzelają zbyt wielu goli, gra w ofensywie sprawia im pewne trudności.

$$
\text { (F, 08.06.2012, s. V) }
$$

Z Rosją ma być inaczej, choć dzisiejsi rywale grają lepiej, szybciej i bardziej ofensywnie niż Grecy. Szybki atak po odbiorze piłki to najgroźniejsza broń rywali.

(GWS, 12.06.2012, s. 1)

wskazywały na emocje, jakie wywołują wśród Polaków:

Jeśli okaże się bezradną już na poziomie meczów grupowych z rywalami niewdzięcznymi, acz nie powodującymi strachliwego drżenia łydek - będziemy kręcić nosem. 
obrazowały szanse polskiej reprezentacji w pojedynkach z nimi:

Rywale są jednak w zasięgu kadry Smudy i dla tej drużyny warto, byśmy się zjednoczyli.

(F, 08.06.2012, s. II)

Na drodze stali Czesi i trudno sobie wyobrazić łatwiejszego rywala na tych mistrzostwach.

(DŁE, 18.06.2012, s. 2)

Jak zatem komentowano dobór przeciwników? Przed inauguracją wskazywano, że wylosowanie takich, a nie innych reprezentacji jest darem od losu:

Z drużynami światowej czołówki wygrywamy ostatnio raz na ćwierć wieku, więc bogowie futbolu zesłali nam w losowaniu Rosjan, Czechów i Greków — obsadę grupy słabszą niż na jakiejkolwiek poprzedniej grupie mistrzowskiej.

doceniano jednak również klasę rywali:

(GW, 18.06.2012, s. 1)

Grecy to nie są Niemcy, Hiszpanie, Włosi, Francuzi czy Holendrzy, czyli drużyny z samego szczytu futbolowej hierarchii. A jednak pokonać ich będzie piekielnie ciężko.

(GWS, 08.06.2012, s. 3).

Podczas opisywania naszych południowych sąsiadów uwypuklano, że zawsze dobrze się nam grało z czeską reprezentacją, na dodatek obecnie brakuje w niej gwiazd światowego formatu, najlepsi gracze nie wystąpią z powodu kontuzji:

Nie w zderzeniu z nieosiągalnymi piłkarskimi bogami, ale z nękaną kłopotami i chwilowo niemal pozbawioną pomnikowych postaci drużyną czeską - w większości tak anonimową, jak już dawno anonimowa na żaden wielki turniej nie jechała.

(PS, 18.06.2012, s. 6)

W ostatniej kolejce grupowej nasi mieli przeć po najefektowniejszy sukces od 30 lat, więc dostali za przeciwnika Czechów — drużynę, na której kompleks nie cierpią, znacznie uboższą niż przed laty, pozbawioną w piątek swego schorowanego lidera.

(GW, 18.06.2012, s. 1)

Po odpadnięciu Polaków z turnieju z kolei rozkładano na czynniki pierwsze postawę naszych reprezentantów we wszystkich trzech meczach:

A zespół? Z Grecją zagrał bardziej sercem niż rozumem. Z Rosją — duszą, rozbudzając w kraju niebywały optymizm. Mecze skończyły się remisami, a od porażki dzieliło nas niewiele. Z Czechami musieliśmy wygrać. Jak było — widzieliśmy.

(GWS, 18.06.2012, s. 7).

Charakterystyczne było też opisywanie gry kolejnych przeciwników poprzez zestawianie ich z drużynami, z którymi rozgrywaliśmy już mecz. Zastanawiano się, jakie mają cechy wspólne, w czym są lepsi, a w czym gorsi od poprzednich rywali, jaki styl gry preferują, czym mogą nas zaskoczyć, porównywano warunki fizyczne zawodników oraz poszczególne formacje:

Rosja to, przynajmniej w teorii, dużo silniejszy przeciwnik od Grecji.

(PS, 09.06.2012, s. 8) 
Rosjanie grają dość czytelny futbol. Łatwiej rozszyfrować ich grę niż grę Czechów czy Greków, ale to nie znaczy, że łatwiej będzie zneutralizować ich atuty.

(GWS, 12.06.2012, s. 2)

O ile jednak Grecy starali się grać ekonomicznie, o tyle Rosjanie nie będą kalkulować.

(GWS, 12.06.2012, s. 2)

Rosjanie grają piłkę bardziej czytelną i łatwiejszą do rozszyfrowania niż Grecy.

$$
\text { (F, 12.06.2012, s. VI) }
$$

Czesi nie są tak konsekwentni w obronie jak Grecy, ani tak groźni w ataku jak Rosjanie.

(GWS, 16-17.06.2012, s. 2)

W odróżnieniu od naszych poprzednich rywali zmiennicy są bardzo podobnej klasy, jak gracze z podstawowej jedenastki. To jest właśnie podstawowa różnica między Czechami a Rosją i Grecją.

(GWS, 16-17.06.2012, s. 2)

W przeciwieństwie choćby do Greków Czesi zdecydowanie lepiej czują się w ataku.

(GWS, 16-17.06.2012, s. 2)

Dziennikarze chcieli w ten sposób zaznaczyć, na jakie elementy kibice powinni zwrócić szczególną uwagę podczas meczu, podpowiadali, czego można oczekiwać w nadchodzącym spotkaniu.

Częste było również zestawianie polskich reprezentantów z ich przeciwnikami. Porównywano, które zespoły prezentują lepszy styl na murawie, kto opracował lepszą taktykę, zastanawiano się, czy zauważalny jest postęp w grze:

W bezpośrednim starciu z Rosjanami wypadliśmy dużo lepiej od nich. Pokazaliśmy, że mamy nie tylko umiejętności, ale też wielkie serce do gry.

$$
\text { (F, 13.06.2012, s. VIII) }
$$

Wydaje się, że Polacy mają w tej chwili silniejszy zespół niż Czesi, są świetnie umotywowani, a w drużynie Franciszka Smudy jest lepsza atmosfera niż wśród podopiecznych trenera Michala Bilka.

$$
\text { (DŁE, 16-17.06.2012, s. 1) }
$$

Między pierwszym występem a trzecim nie poprawiła się jakość gry, co udało się osiągnąć np. Czechom i Grekom.

(DŁE, 18.06.2012, s. 2)

Polacy nie mieli kilku wariantów, jak np. Czesi, którzy inaczej grali do przerwy i zupełnie zmienili oblicze taktyczne w drugiej połowie.

(DŁE, 18.06.2012, s. 3)

Odniesienie do Rosjan - którzy podobnie jak Polacy nie awansowali do ćwierćfinału — zastosowano w celach terapeutycznych — przynajmniej pozornego ukojenia i pocieszenia, zniwelowania żalu:

drużyna Dicka Advocaata była uznawana za faworyta naszej grupy, więc skoro ona odpadła z turnieju, to my — uważani przecież za zespół średniej klasy — nie powinniśmy czuć aż tak 
wielkiego rozgoryczenia: Marne to pocieszenie, ale... Skoro my czujemy się rozczarowani, to co mają powiedzieć Rosjanie...

(DŁE, 18.06.2012, s. 1)

W doniesieniach prasowych dotyczących Euro 2012 - co nie dziwi, bo przecież po raz pierwszy dane nam było organizować tak duży turniej — dominował temat reprezentacji Polski. Nie zabrakło jednak artykułów szczegółowo i precyzyjnie analizujących postawę naszych grupowych rywali. By przekaz stał się atrakcyjny dla odbiorcy, sięgano po różnorodne zabiegi językowe. W celu jak najlepszego zobrazowania postawy Polaków, Greków, Rosjan i Czechów powszechnie używano rozbudowanych metafor, porównań, peryfraz czy epitetów, zestawiano ze sobą cechy poszczególnych narodów. Ciekawym rozwiązaniem było powoływanie się na kontekst historyczny, co powodowało, że nie patrzono na mecz, jako tylko na widowisko sportowe, ale także istotne wydarzenie dla dziejów naszej ojczyzny. Przy opisie można było odnaleźć także odwołania do kultury danego kraju — dziennikarze posługiwali się nawiązaniami mitologicznymi, wymieniali elementy charakterystyczne dla danego regionu Europy czy przytaczali popularne przysłowia.

Autorzy starali się oddać emocje towarzyszące zmaganiom piłkarskim, chcieli pokazać mocne i słabe strony zespołów, co ważne — nie dyskredytowali przy tym rywali, dbali o to, by opis był wiarygodny i w dużej mierze obiektywny. Opozycja my — oni nie miała wydźwięku radykalnie dyskredytującego przeciwnika, jak zdarza się to często $\mathrm{w}$ dyskursie politycznym, ale przyjmowała łagodną formę - $\mathrm{w}$ ten sposób dziennikarze zagrzewali do sportowej walki, jednocześnie doceniając rolę przeciwnej drużyny. Wszystkie wymienione zabiegi językowe nie tylko przekazywały informacje, ale służyły także celom ornamentacyjno-estetycznym, impresywnym i ekspresywnym.

\section{Bibliografia}

Grochala B., 2012, Język internetowej relacji sportowej na żywo [w:] Język nowych mediów, Michalewski K. (red.), Łódź, s. 21-30.

Koper M., 2009, Emocje w języku sprawozdawców sportowych [w:] Rejestr emocjonalny języka, Wojtczuk K., Machnicka V. (red.), Siedlce, s. 67-76.

—, 2003, „Poezja futbolu”. Kilka uwag o języku sprawozdawców sportowych [w:] Język Polski. Współczesność. Historia, Książek-Bryłowa W., Duda H. (red.), Lublin, s. 51-62.

OżDżYŃSKI G., 1994, Wartościowanie w mówionym tekście komentarza telewizyjnego na przyktadzie transmisji sportowej, „Poradnik Językowy”, nr 1-2, s. 24-36. SzKUdLAREK-ŚMIeChOwicz E., 2006, Wyrażanie emocji $w$ telewizyjnych komentarzach sportowych [w:] Wyrażanie emocji, Michalewski K. (red.), Łódź, s. 353-365. 